\title{
SIR PETER MAXWELL DAVIES: A PERSONAL REFLECTION
}

\author{
Christopher Fox
}

The death on 14 March of Sir Peter Maxwell Davies was very properly marked in British broadsheet obituary columns and broadcast news bulletins, as befitted the passing of a knight of the realm and the former Master of the Queen's Music. Social media were full of messages mourning the loss of a musician whose generous advocacy of music had touched many lives, and it is to that latter, more informal category of tribute that I would like to add a few words.

For many of us whose awakening to new music came in the late 1960s, Maxwell Davies was a key figure in British musical life. In particular, the creation of the Pierrot Players and then the Fires of London, as they became when Max took sole direction of the ensemble, provided a focal point both for Max's own compositional energies and for the development of modern music in Britain. The Fires were a group of musicians with an unusual mixture of great virtuosity and formidable musical intelligence; Alan Hacker, Duncan Druce and Jennifer Ward Clarke were as equally influential in the development of the historically informed performance of early music as they were in championing new music, and Stephen Pruslin was both a superb keyboard player and a consistently perceptive writer on new music, Max's in particular. Together with the flautist Judith Pearce and percussionist Barry Quinn they constituted an ensemble that took new music seriously and in turn demanded to be taken seriously themselves.

Max's response to the challenge of writing for such a demanding group was a series of increasingly spectacular works whose ability to shock the concert-going public reached its peak with Eight Songs of a Mad King (1969). Eight Songs remains an iconic work - literally so in the beautiful calligraphy of its hand-drawn score which Boosey and Hawkes made available in a handsome facsimile edition soon after the work's premiere - and one whose vocal, instrumental and theatrical imagery retains much of its original visceral power. Remarkably for a work whose demands on its performers seemed so extreme Eight Songs became one of Max's most performed works. Some years after they had both given up playing with the Fires I got to know Alan Hacker and Duncan Druce, and we often talked about their role in creating this early Fires repertoire. Druce tended to be rather dismissive of Eight Songs - for him it lacked compositional sophistication - but Hacker was fascinated by the way in which music which originally seemed so dependent on the special skills of its first performers, vocalist Julius Eastman in particular, could be taken up so widely.

For me, those early Fires works remain the highpoint of Max's output; they are strange, troubling works which inhabit an aesthetic 
territory crossed by many apparently incompatible paths, from medieval music, from Bussotti, from Schoenberg. It is clear, however, that these works were achieved at some considerable psychological cost; Max's creative survival depended on his physical relocation to the Orkney islands and his metaphorical relocation to a safer musical landscape where the emotional conflicts tended to be external rather than internal. The main characters of works like The Martyrdom of St Magnus (1976) and The Lighthouse (1979) suffer terrible fates but they are the victims of forces larger than themselves, rather than being consumed, like the dancer-protagonist of Vesalii Icones (1969) or the mad king, by their own inner contradictions: 'I am not ill but I am nervous'.

As Max settled into this new land- and seascape, I worked back through his earlier music, discovering the rich complexities of works like the Second Fantasia on John Taverner's In Nomine (1964) and the abrasive mix of consonance and dissonance in the carols of O Magnum Mysterium (1960). There were things to enjoy in the new music too: the first works from Orkney include the extraordinarily beautiful Stone Litany (1973) for voice and orchestra, setting runes carved in the walls of the neolithic burial site at Maeshowe, the First Symphony (1976) and the dazzling chamber orchestral work, A Mirror of Whitening Light (1977).

It was around this time that Jonathan Harvey invited Max to give a lecture at Southampton University where I was then a postgraduate student and it remains one of the most memorable lectures I have ever attended. Max described his working routine in Hoy and how on his walks across the island he would project spans of music across the landscape, fixing the end of an oboe line, for example, on an outcrop on the horizon. He talked about finding an individual compositional voice and suggested that young composers were wasting their time if they thought they could do this without first developing technical competence. When he was asked how he got the isorythmic canons of the Hymn to St Magnus (1972) to cohere harmonically his answer was typical: 'I just keep doing it until it comes right'. The implication was clear: everything depended on hard work and technique.

In the music of the decades that followed it sometimes seemed as if Max had become a slave to his own dictum. Max the composer worked very hard - there are the ten Strathclyde concertos, the ten Naxos quartets, the ten symphonies - and Max the conductor worked hard too, touring extensively, usually as an interpreter of his own music. His compositional technique, almost always based around permutated transformations of plainsong melodies, supplied him with an endless supply of pitch material, all of which already had some sort of significance, for him at least. Amidst this prodigious production there are some fine pieces - the seventh of the Naxos Quartets (2005) has the architectural grandeur of the Borromini buildings that inspired it, and the Ninth Symphony (2012) is a splendidly vigorous work, turbo-charged with extra brass - but often the working seemed to be as important to Max as the work it produced.

The Ninth Symphony is dedicated to Queen Elizabeth II, and no account of Max's contribution to British musical life would be complete without mention of his revitalisation of the post of Master of the Queen's Music. Max's commitment to music as a social and educative art was never in doubt, from his pioneering work as a schoolmaster in Cirencester to the foundation of the St Magnus Festival in Orkney, and he seized on the possibilities of the Mastership with 
characteristic energy and dedication. In a period during which the teaching of music in British schools has been under continuous threat he became a forceful spokesman for the importance of music both in children's development and in the wider society.

Now that Max has gone we are left with a vast body of music; the most recent pieces listed on maxopus.com, the website devoted to his music, carry opus numbers in the 330s. Some are relatively slight, others were written for specific occasions, and some, as I suggested earlier, may be primarily interesting as evidence of what hard work and technique can produce, but there is surely much that will stand the test of time. Max often claimed that the instrumentation in his later work was essentially functional, there to make clear the contrapuntal layers within the music, and his own performances of his orchestral music had a similarly utilitarian approach, but I suspect that the later works are full of undiscovered beauties that will emerge in the right hands. To quote from words Max wrote in the March 1977 issue of TEMPO on the death of Benjamin Britten, we have lost a 'supreme creator of music'; to quote from the last rune in Stone Litany, 'Max the Mighty carved these runes'. 